\title{
Application Architecture of Car Automobile Dealers Using Enterprise Architecture Planning (EAP)
}

\author{
Cornelius Juvian Limanto ${ }^{1}$, Lily Puspa Dewi ${ }^{2}$, Adi Wibowo ${ }^{3}$ \\ ${ }^{1}$ College of Business Information System, Petra Christian University, Indonesia \\ ${ }^{2}$ M.Kom, Informatics Engineering Department, Petra Christian University, Indonesia \\ ${ }^{3}$ M.Tech, Informatics Engineering Department, Petra Christian University, Indonesia
}

\begin{abstract}
Mandala Company is one of company which engaged in the field of car automotive dealer. The company has several business processes i.e. sales units and test drive, service, sales and purchases of spare parts. At this time not all business processes in this Company is supported by the existence of an information system. Existing information systems currently only support part of unit sales, finance, and accounting. Based on these circumstances to integrate the information systems of unit sales, service, sales and spare parts purchases, so we will do some analysis for Mandala Company using Enterprise Architecture Planning (EAP). Steps being taken are doing business modeling and business strategy. After that, the next stage is to look at the condition of an information technology company that exists today. Then it will be making data architecture, application architecture, and technology architecture. Application architecture produces some applications are needed from the company.
\end{abstract}

Keywords: Enterprise Architecture Planning, Application Architecture, Information System, Automotive

\section{Introduction}

Mandala Company is a car automotive dealership company that was established in April 2014. The company has several business processes that support these companies. Mandala Company currently has operational activities, namely the sale of new units. The main activity of unit sales in the company's activities X. unit sales process is currently supported by a software or information system which is created by a freelance programmer. The program has several features that support the sales process to accounting. But the lack of this feature there is some process that is done manually, such as booking a test drive, and the reporting of the purchase of the unit, in addition to that the company wanted a new program that can integrate between 3 existing business of activity. Therefore, analysis enterprise architecture using Enterprise Architecture Planning (EAP) to design an information system strategy. The results of the design of information systems in the form of a blueprint that contains the company's needs. The Blueprint will generate an application architecture that contains a recommendation or an alternative option in the form of information systems in the priority scale of the needs of the company.

\section{Enterprise Architecture Planning}

The Enterprise Architecture Planning (EAP) methodology was introduced by Howard Spewak in 1992. The EAP contains of activities processes including Data, Application, and infrastructure or technology. Enterprise Architecture can produce a blueprint of information technology in tune with the business. Architecture defines what is required and plans to define when it will be implemented. Steps enterprise architecture planning can be seen in Fig.1.

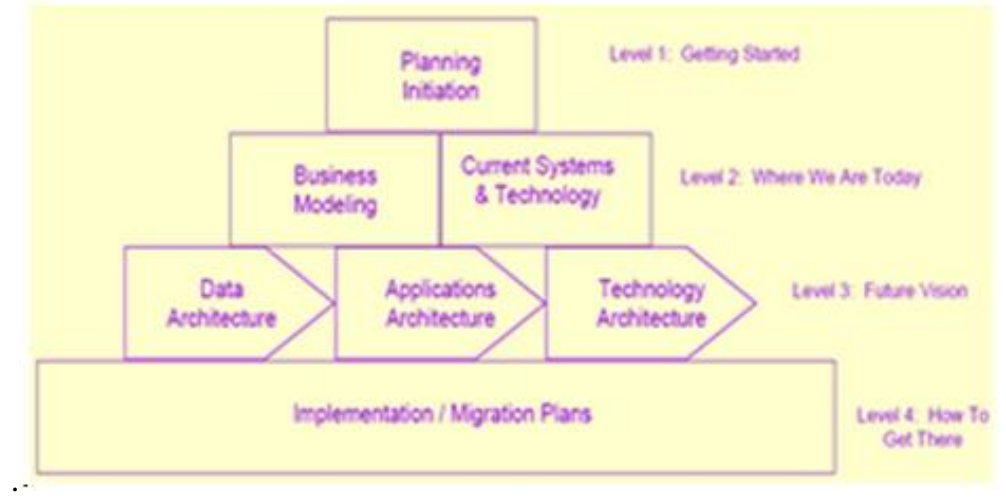

Fig.1: Enterprise Architecture Planning methods 
Description of Figure 1:

Planning Initiation: Preplanning phase to setting all the things in place to be able for using EAP approach to creating an EA.

Modeling business processes

Doing business process modeling runs based on the data of business processes that occur in financial.

- The current system and the technology

Define and document current (as-is) applications systems (components and services) and supporting technology platforms to the level of detail required and defined in the Planning Initiation step

\section{Data Architecture}

Define major kinds of data to form basic vocabulary for business language.

\section{Application Architecture}

Identifying the systems required to support the business, the team will be equipped to address operational capabilities and characteristics in applications and components (and services) that are required to manage and utilize data and information

\section{Technology Architecture}

This phase is fitting sometimes hundreds of potential and current technologies (components) to enable different capabilities that the enterprise will require, to implement the architecture

- Implementation and migration plan

Defines the order for the implementation of the application, implementation schedules, analyzing the costs and benefits as well as provide measures of migration from the current state to the desired state in the future [3].

1. Functional Decomposition Diagram

\section{Result}

i. Car Sales Process

The process is a unit sales, processes are:

a. Create Data customer

b. Create vehicle orders

c. Create work order variation

d. Create scrap relocate unit

e. Acceptance Letter from vendor variations

f. Checking of variation

g. Making delivery letter to customer

h. Additional accessories completeness check

i. Delivery unit to the customer

j. Receive the payment

k. Request feedback from customers

2. Services Process

This is the process of sales service:

a. Making customer master

b. The making worksheets and estimation

c. The making of a work order service

d. The execution of service is based on the work order

e. Receive payment or settlement of service fees

3. Purchasing Spare parts process

a. Do stock opname

b. Checking of stock.

c. The Making purchase order

d. Ordering spare parts.

e. Receipt of the invoice.

f. Receipt of spare parts.

g. Update stock items.

h. Bill payment to a supplier of spare parts

4. Sales of Spare parts process

a. Acceptance of purchase customer data

b. Checking the stock of spare parts

c. Setting up the goods

d. Create of sales order spare parts

e. Accept the payment of spare parts

5. Booking test drive process

a. Customers fill out the form test drive

b. The salesman noticed schedule test drive

c. Do a test drive on schedule 
6. Payroll process

a. Calculation of attendance

b. Upload to payroll systems

c. Print a receipt.

d. Receipt Storage.

7. Recruitment Process

a. Opening of the vacancies

b. Advertising

c. Admission of the prospective employee

d. Interview

e. Selection of prospective employees

f. Recruitment

2. Application Architecture

The applications are designed based on the classification of the information system on architecture data. There are six sub-system design Mandala Company among other unit of sales sub-systems, service and spare parts sub-system, purchasing of spare parts sub system, financial and accounting sub-systems and personnel sub-systems.

3. List of Application per Sub System

- Unit of sales sub-systems

The necessary database: Tbl_candidates_category, Tbl_candidates_of_prospect motor, Tbl_Testdrive, Tbl_calendar, Tbl_period, Tbl_Customer, Tbl_unit, Tbl_color, Tbl_type_of_unit, Tbl_of_Detail_type, stock_car_Units, Vehicle_order Detail_of_accessories, Tbl_Promo, Work_order_variasi, Tbl_Vendor_variasi, scrap relocate units, Tbl_Delivery_letter, Tbl_Complaint.

- $\quad$ Application: Test Drive and sales Information system

- Information Systems Applications for test drive and sales are designed using web-based because it is easier to do maintenance, checking schedules, and made accessible from different places

Maintain data master

Scheduling

This feature to create, modify, and save the master schedule a test drive, and master unit sales. Master Test drive schedule contains the date, time, Car units, customers who book a test drive and name sales. Master unit sales contain customer data, sales data unit, type of payment and heresy to be performed.

- Preparing report:

- Test drive reports,

- Car sales report,

- Data customer report,

- $\quad$ Stock of car units report.

- Data complaint report

- Service and spare parts sub-systems

- The necessary database: Tbl_customer_service, Tbl_car_unit, Tbl_estimation_letter, Work_order, Tbl_spare parts, Tbl_work_of services, Tbl_checkout_spareparts, Tbl_detail_check_out_spareparts, Tbl_sales_order.

- $\quad$ Application: Service and Spare parts information system

- Information System Application Service is designed in the form of web-based because it is easier to do maintenance, and can be connected with the division field or in the workmanship of service and spare parts warehouse. And for this application we can add some feature like reminder of service, which the application can show all of the customer and the last time of service. So, the customer care can remind the customer for next service.

- Maintain data master.

This feature to create, modify, and save the master of estimation letter, work order service, master work of services, master data customer.

- Preparing report:

- Sales of services report

- Spare parts needed report

- Sales of Spare parts report

- Data customer service

- Data customer unit

- Scheduling of reminder service. 
- Purchasing of spare parts sub system

The necessary database: Tbl_Purchase_Order, Detail_purchase_order, Purchase_return, Detail_purchase_return, check in, detail check in, Stok, Stok_Opname, Tbl_spareparts, Tbl_checkin_spareparts, Tbl_detail_check_out_spareparts.

Application: Spare parts Information System

Application of information system of Spare parts are designed in the form of the web because it's easier to do the repair and supervision on a server computer.

Maintain data master.

This feature to create, modify, and save purchase order, master data of stock, and master data customer.

Preparing report:

- Stock reports.

- Purchase order reports.

- Spare parts acceptable reports.

- Financial and accounting sub-system

- The necessary database: Tbl_invoice, Tbl_record_debt, Tbl_debt_payment, Tbl_cash book, Tbl_cashbook_out.

- Application: financial and accounting information system

The design of Financial information system in the form of web-based applications with web-based applications because it's easier to do the repair and supervision on the server computer.

- Accounts payable

Keep all your accounts payable data company

Cash Receipts

Keep all the cash receipts data of the company

Recording invoices

Create a data record company received invoice

Payment of debt

Features to perform the recording of debt payments made by the company.

- Journaling

Journaling accounting the entire company's business activities ranging from accounts payable, cash receipts, debt, debt settlement, credit, and credit repayment.

- $\quad$ Preparing report:

- Invoice Report

- Cash expense reports

- Cash receipt Report

- Debt Report

- Report repayment of debt

- The income statement

- Personnel sub-system

- The necessary database: Tbl_Job, Tbl_employee, Tbl_payroll, Tbl_attendance, Tbl_appraisal, Tbl_detail_of_appraisal, Tbl_Training, Tbl_detail_of_training.

Application: Personnel Information system

Personnel information system application this is designed with a web-based application because the repair and supervision can be done on a computer server, as well as make it easier for maintenance applications.

Maintain Data master

- Employee attendance feature connected with finger scanners to calculate absences of employees. Hours and hours of coming home employees will be known so that it can calculate how many minutes of delay and overtime of employees.

- The calculation of salary. This feature automatically calculate the amount of the salary of each employee based on the number of incoming work, delays, and overtime hours.

- Create, change and save assessment Data which is can be stuffed with the filling date of the assessment, the type of assessment and value of assessment.

- Preparing Report:

- Employee Data

- $\quad$ Payroll reports

- Attendants reports

- Assessment reports

- Training reports. 
4. Classification of Application using Mc Farlan Strategy Grid

Mc Farlan strategic grid useful for mapping applications based on their usefulness to the organization. Mapping is done in four quadrants, namely strategic, high potential, key operation, and support. From the results of the mapping is done, then it was noted the contribution of information systems applications to the company / organization and the development in the future. These are the classification of application using MC Farlan Strategy Grid can see in fig 2.

\begin{tabular}{|l|l|}
\hline Strategic & High Potential \\
\hline & $\begin{array}{l}\text { Customer } \\
\text { Management and reminder } \\
\text { services }\end{array}$ \\
\hline Key Operational & Support \\
\hline - Test Drive Information System & - Back Up Database Server \\
- Service and sales of spare parts & - Website \\
- Information System Purchasing of spare parts & \\
- Information System & \\
- Farehouse Information System & \\
- Information and accounting & \\
- Personnel Information system & \\
\hline
\end{tabular}

Fig 2. Classification of application

5. Enterprise Wide Application

In addition to the applications on each sub-system, there is an application to be executed by the entire system. These are applications that run on the entire system:

- Website company profile

- Single Sign On Service

- Backup Database Server.

\section{Conclusion}

Based on the design of the application architecture that has been determined, then the application enters the category of High Potential is Customer Relation Management and reminder for services. Applications that are signed in the support category is backing up the database servers and websites of the company profile. While entering the category of key operational information systems is test drive; sales information system; service and sales of spare parts information system; purchasing of spare parts information system; warehouse information system; financial and accounting information system; personnel information system; this company will use website, single sign on to support their process business.

\section{References}

[1] Khusna, A.N, Kusrini \& Arief R.M. (2012).Pemodelan arsitektur enterprise untuk strategi pengelolaan aplikasi bidang tanggap darurat bencana. Program Studi Teknik Informatika Universitas Ahmad Dahlan, 722-729

[2] Spewak, S.H , Enterprise Architecture Planning (Developing a Blueprint for Data, Application and Technology), Jhon Wiley \& Sons, Inc (2012)

[3] Minoli, D. (2008) Enterprise Architecture A to Z. USA: Taylor and Francis Group.

[4] Spewak, S.H., UPDATING THE ENTERPRISE ARCHITECTURE PLANNING MODEL, Journal of Enterprise Architecture (2006)

[5] Rosmala, D., \& Falahah. (2007). Pemodelan proses bisnis B2b dengan BPMN (Studi kasus pengadaan barang pada divisi logistik). Institut Teknologi Nasional Bandung. ISSN 1907-5022, J63-J67

[6] Osterwalder, A., Pigneur, Y. (2010). Business Model Generation. Canada: John Willey and Sons.

[7] Mayadewi, P. (2016). Perencanaan Arsitektur Enterprise Untuk Mendukung Strategi Pengembangan Sistem Informasi. Manajemen Informatika, Politeknik Telkom. 